\title{
Evaluation and quantification of surface air temperature over Eurasia based on CMIP5 models
}

\author{
Xiaoqing Peng ${ }^{1}$, Tingjun Zhang ${ }^{1}$, Oliver W. Frauenfeld ${ }^{2, *}$, Kang Wang $^{3}$, Wen Sun ${ }^{1}$, \\ Jing Luo ${ }^{4}$
}

\author{
${ }^{1}$ Key Laboratory of Western China's Environmental Systems (Ministry of Education), \\ College of Earth and Environmental Sciences, Lanzhou University, Lanzhou 730000, PR China \\ ${ }^{2}$ Department of Geography, Texas A\&M University, College Station, TX 77843-3147, USA \\ ${ }^{3}$ Institute of Arctic and Alpine Research, University of Colorado at Boulder, Boulder, CO 80309, USA \\ ${ }^{4}$ State Key Laboratory of Frozen Soil Engineering, Northwest Institute of Eco-Environment and Resources, \\ Chinese Academy of Sciences, Lanzhou 730000, PR China
}

\begin{abstract}
Parts of Eurasia underlain by large areas of frozen ground that are both sensitive to, and an indicator of, climate change. Previous studies have investigated the effect of climate change on frozen ground; however, those studies did not quantify the past or projected climate change effects for specific frozen ground regions. This study applied surface air temperature from the Climatic Research Unit (CRU) data set and the multi-model ensemble mean of 16 Coupled Model Intercomparison Project Phase 5 (CMIP5) models to evaluate past and projected surface air temperature changes, and quantify changes in different frozen ground regions. Results indicate that CMIP5 can simulate surface air temperature over Eurasia well, and there is slightly better performance of CMIP5 ensemble averages in the late 20th century than in the early 20th century. Over the Eurasian continent, time-series of ensemble area-averaged mean annual air temperatures (MAT) from CMIP5 increased at about $0.074^{\circ} \mathrm{C}$ decade $^{-1}$ during $1850-2005$, and are projected to increase by $0.078-0.719^{\circ} \mathrm{C}$ decade $^{-1}$, depending on future emission pathways, during 2006-2100. Compared to the period $1986-2005$, the temperature is predicted to be $1.68-6.41^{\circ} \mathrm{C}$ higher during 2081-2100. Changes of MAT demonstrate that the fastest increase will occur in continuous permafrost regions, next in discontinuous permafrost regions, followed by sporadic, isolated, and relict permafrost, and finally non-permafrost regions. Overall, these results can be used to help estimate and project cryospheric changes.
\end{abstract}

KEY WORDS: Eurasia $\cdot$ CMIP5 $\cdot$ Permafrost $\cdot$ Surface air temperature

\section{INTRODUCTION}

Combining land and ocean surface air temperature data, the global mean air temperature increased by $0.85^{\circ} \mathrm{C}$ during the period 1880 to 2012 . The single longest time-series data set available showed $0.78^{\circ} \mathrm{C}$ higher temperature during 2003-2012, relative to 1850-1900 (IPCC 2013). There has also been a statistically significant increase in the global average land surface air temperature of $0.75^{\circ} \mathrm{C}$ during 1906 to 2005. This warming trend is due to increases of

${ }^{*}$ Corresponding author: oliver.frauenfeld@tamu.edu anthropogenic greenhouse gas concentrations, especially since the mid-20th century (IPCC 2013, Xu et al. 2015).

In high-latitude regions, temperatures have increased by $0.6^{\circ} \mathrm{C}$ decade ${ }^{-1}$ during the last $30 \mathrm{yr}$, double the global average (IPCC 2013). This increased warming causes frozen ground to thaw (Brown \& Romanovsky 2008, Romanovsky et al. 2010), increases soil microbial activity, and leads to the decomposition of substantial quantities of organic carbon that is released into the atmosphere (Schuur

(C) The authors 2019. Open Access under Creative Commons by Attribution Licence. Use, distribution and reproduction are unrestricted. Authors and original publication must be credited. 
et al. 2015). The magnitude and speed of climate warming have been much greater in high latitude regions compared to lower latitudes (Rothrock et al. 1999, Serreze et al. 2000, Chapin et al. 2005, Screen \& Simmonds 2010, Jeong et al. 2012).

General circulation models (GCMs) are considered to be useful tools to evaluate past and present climate and to project future changes (Shackley et al. 1998, Xia et al. 2014). GCMs can therefore be applied to simulate surface air temperatures in cold regions such as central Asia, as well as arid and semiarid areas including parts of China and the United States (Xu \& Xu 2012, Guo et al. 2013, Jiang and Wu 2013, Sillmann et al. 2013, Xia et al. 2014, Wuebbles et al. 2014).

Surface air temperature is regarded as one of the most significant variables affecting frozen ground changes. In general, Eurasia-defined here as including the former USSR and China, as in Zhong et al. (2018) - occupies about $33.45 \times 10^{6} \mathrm{~km}^{2}$, approximately $33.7 \%$ of the Northern Hemisphere's land surface (Fig. 1, Table 1). This includes a large area of permafrost and seasonally frozen ground (Brown et al. 1998, Zhang et al. 2003). Permafrost exists at high latitudes and high elevations in Eurasia. Eastern and

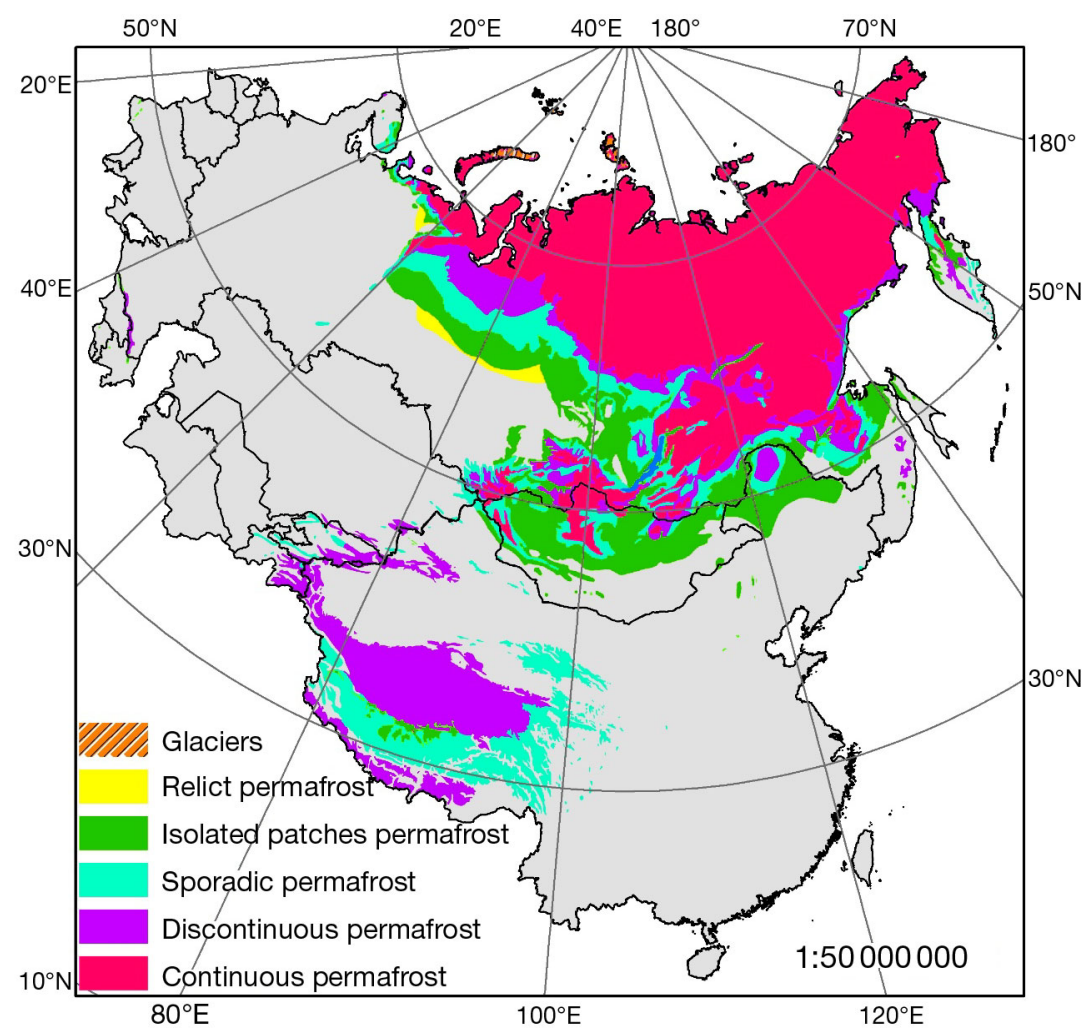

Fig. 1. Spatial distribution of permafrost over Eurasia, defined as the former USSR and China (Zhong et al. 2018). Permafrost is divided into continuous, discontinuous, sporadic, isolated, and relict
Table 1. Statistics of permafrost area extents over Eurasia

\begin{tabular}{|lcc|}
\hline Type & Area $\left(10^{6} \mathrm{~km}^{2}\right)$ & Fraction (\%) \\
\hline Continuos permafrost & 7.09 & 21.2 \\
Discontinuos permafrost & 2.56 & 7.6 \\
Sporadic permafrost & 2.21 & 6.6 \\
Isolated permafrost & 2.29 & 6.8 \\
Relict permafrost & 0.12 & 0.4 \\
Glaciers & 0.05 & 0.2 \\
Total land & 33.45 & 100 \\
\hline
\end{tabular}

central Siberia are dominated by continuous permafrost. The area north of the Tibetan Plateau is underlain by discontinuous permafrost. In general, permafrost exists in sporadic, isolated, and relict patches, as one moves equatorward and to lower elevations. Summary statistics of permafrost areal extent (Table 1) show that continuous permafrost regions occupy approximately $7.09 \times 10^{6} \mathrm{~km}^{2}$, or $21.2 \%$ of the land surface of Eurasia. Discontinuous permafrost regions rank second, at $2.56 \times 10^{6} \mathrm{~km}^{2}$, or $7.6 \%$ of the land surface, followed by sporadic, isolated, and relict permafrost regions. Glaciers occupy $0.05 \times 10^{6} \mathrm{~km}^{2}$, or $0.2 \%$ of the land surface. Excluding glaciers, the area of permafrost is approximately $14.27 \times 10^{6} \mathrm{~km}^{2}$, equal to $42.6 \%$ of the Eurasian land surface.

Considerable changes are to be expected in the earth's frozen ground environments and these are likely to be particularly important in Eurasia, given its large extent of frozen ground. Surface air temperature is a direct and important variable driving and responding to these changes. Previous studies have not explicitly evaluated climate change in different frozen ground regions. Thus, assessing these surface air temperature changes is useful for identifying and assessing frozen ground conditions, and highlighting potential improvements for future modeling and mitigation efforts.

In this study, we investigate surface air temperature during the period 1850 to 2100 for Eurasia based on the output from 16 Coupled Model Intercomparison Project Phase 5 (CMIP5) models. The unique and novel contribution of our study is to quantify surface air temperature changes within the different permafrost zones of Eurasia and compare these changes to 
other regions, thereby putting climate change in Eurasian permafrost areas into a global context. To accomplish this, we (1) compare the CMIP5 surface air temperatures to the observed surface air temperatures in the 20th century, (2) evaluate projected surface air temperature variability over Eurasia for the 21 st century, and (3) quantify surface air temperature changes in different frozen ground regions from the past through the future.

\section{DATA AND METHODS}

We used monthly surface air temperature from the Climatic Research Unit (CRU) time-series (TS) 3.22 and from CMIP5, and the digital version of the International Permafrost Association (IPA) circum-arctic map of permafrost (Brown et al. 1998, Zhang et al. 2003).

\subsection{Frozen ground map}

Based on the IPA map, we identified permafrost areas in Eurasia. The permafrost categories evaluated here include continuous permafrost (CPF), discontinuous permafrost (DCPF), the combination of sporadic, isolated, and relict permafrost (SIRPF) areas; the remaining areas were categorized as non- permafrost (NonPF). These categories were used to calculate the area extent of each permafrost type across Eurasia, as well as boundaries for quantifying surface air temperature changes in these regions.

\subsection{CRU surface air temperature}

The CRU v.3.22 TS data set of surface air temperature, developed by the University of East Anglia (https://crudata.uea.ac.uk/cru/data/hrg/cru_ts_3.23), is composed of 1901-2013 monthly grids of observed climate data. It is provided at a horizontal latitudelongitude resolution of $0.5 \times 0.5^{\circ}$ and consists of surface air temperatures interpolated from meteorological stations across global land areas (Harris et al. 2014). For model evaluation, gridded data sets are commonly used due to their gridded output, global spatial coverage, and representative scale (Sillmann et al. 2013). The CRU surface air temperatures were used to determine the CMIP5 models' performance.

\subsection{CMIP5 surface air temperature}

To evaluate CMIP5 model projections of climate change in Eurasia, we used surface air temperature output from 16 CMIP5 models, developed by various international research institutes (Table 2; http://

Table 2. Coupled Model Intercomparison Project Phase 5 (CMIP5) climate models used in this study

\begin{tabular}{|c|c|c|}
\hline Model & Institution and country & $\begin{array}{l}\text { Spatial } \\
\text { resolution }\end{array}$ \\
\hline CCSM4 & National Center for Atmospheric Research, USA & $192 \times 288$ \\
\hline CanESM2 & Canadian Centre for Climate Modelling and Analysis, Canada & $64 \times 128$ \\
\hline FIO-ESM & The First Institute of Oceanography, SOA, China & $64 \times 128$ \\
\hline GISS-E2-H & NASA Goddard Institute for Space Studies, USA & $90 \times 144$ \\
\hline GISS-E2-R & NASA Goddard Institute for Space Studies, USA & $90 \times 144$ \\
\hline IPSL-CM5A-LR & Institute Pierre Simon Laplace, France & $96 \times 96$ \\
\hline IPSL-CM5A-MR & Institute Pierre Simon Laplace, France & $143 \times 144$ \\
\hline MIROC-ESM-CHEM & Japan Agency for Marine-Earth Science and Technology, Atmosphere, Japan & $64 \times 128$ \\
\hline MIROC-ESM & $\begin{array}{l}\text { Japan Agency for Marine-Earth Science and Technology, Atmosphere and } \\
\text { Ocean Research Institute (The University of Tokyo), and National Institute for } \\
\text { Environmental Studies, Japan }\end{array}$ & $64 \times 128$ \\
\hline MIROC5 & $\begin{array}{l}\text { Atmosphere and Ocean Research Institute (The University of Tokyo), } \\
\text { National Institute for Environmental Studies, and Japan Agency for Marine-Earth } \\
\text { Science and Technology, Japan }\end{array}$ & $128 \times 256$ \\
\hline MPI-ESM-LR & Max Planck Institute for Meteorology, Germany & $96 \times 192$ \\
\hline MPI-ESM-MR & Max Planck Institute for Meteorology, Germany & $96 \times 192$ \\
\hline MRI-CGCM3 & Meteorological Research Institute, Japan & $160 \times 320$ \\
\hline NorESM1-M & Norwegian Climate Centre, Norway & $96 \times 144$ \\
\hline bcc-csm1-1-m & Beijing Climate Center, China Meteorological Administration, China & $160 \times 320$ \\
\hline bcc-csm1-1 & Beijing Climate Center, China Meteorological Administration, China & $64 \times 128$ \\
\hline
\end{tabular}


pcmdi9.llnl.gov/esgf-web-fe/; Joetzjer et al. 2013). Each of these models has its own numerical implementations and parameterizations for dealing with frozen ground; see e.g. Oleson et al. (2013) for the technical description of the Community Land Model (CLM) used in NCAR's CCSM4. These model data sets also all use different spatial resolutions, but cover the same period from 1850 to 2100 . We applied the output from 4 CMIP5 experiments: a historical experiment, 1850-2005, and 3 future emission scenarios for 2006-2100 (Taylor et al. 2012). The 3 future scenarios are the representative concentration pathways (RCP) developed for the Intergovernmental Panel on Climate Change (IPCC) Fifth Assessment Report (AR5) - specifically, RCP 2.6, RCP 4.5, and RCP 8.5. Each of these 4 experiments is characterized by different radiative forcing. The historical experiment is forced with observed atmospheric composition changes (Taylor et al. 2012). The RCP 2.6 experiment represents a low level of forcing: before 2100, radiative forcing is $\sim 3 \mathrm{~W} \mathrm{~m}^{-2}$ at its peak, and declines to $2.6 \mathrm{~W} \mathrm{~m}^{-2}$ by 2100 (Van Vuuren et al. 2008). RCP 4.5 is a medium stabilization scenario reaching $4.5 \mathrm{~W} \mathrm{~m}^{-2}$ forcing in 2100, without exceeding or falling below that level (Thomson et al. 2011). The radiative forcing of the RCP 8.5 scenario is $8.5 \mathrm{~W} \mathrm{~m}^{-2}$ in 2100 , and corresponds to the highest greenhouse gas emissions associated with fast population growth and more energy use (Riahi et al. 2011).

\subsection{Methods}

For the model evaluation, we first re-regridded all CMIP5 model outputs and the CRU data set to a common resolution of $1 \times 1^{\circ}$ using a bilinear interpolation (Chen \& Frauenfeld 2014). We used basic statistical methods and error analysis to assess the CMIP5 surface air temperatures relative to CRU observations. We used mean error (ME), mean absolute error (MAE), root mean square error (RMSE), standard deviation of the error (SDE), and correlation (R). We also used a linear trend analysis to compare and estimate the long-term trends in monthly, seasonal, and annual temperatures over Eurasia during the 20th and 21st centuries. Using monthly surface air temperatures, we calculated the mean annual air temperature (MAT) based on the calendar year, and the mean seasonal air temperature (MSAT) for the 4 seasons, i.e. spring (March-May; MAM), summer (JuneAugust; JJA), autumn (September-November; SON), and winter (December-February; DJF).

\section{RESULTS}

\subsection{Surface air temperature evolution}

To evaluate the 16 CMIP5 models' performance relative to the CRU observations, the period 19012005 was extracted from the historical experiment. For that period, the ME ranged between -1.35 and $1.39^{\circ} \mathrm{C}$, and was negative for 10 of the models (Table 3). The MAE of 12 models was less than $1.0^{\circ} \mathrm{C}$, and $0.34^{\circ} \mathrm{C}$ for the ensemble average. RMSE of 10 models was less than $1.0^{\circ} \mathrm{C}$. The smallest SDE is for the ensemble average of the CMIP5 models, $0.42^{\circ} \mathrm{C}$. The largest correlation coefficient was 0.68 , also for the ensemble average of the CMIP5 models.

To further evaluate CMIP5 surface air temperature compared to the CRU observations, we divided the historical period into 2 parts: the early 20th century (from 1901-1950), and the late 20th century (from 1951-2005). MAT derived from the CRU data set was more variable than that derived from the CMIP5 ensemble (Fig. 2). Large variations in MAT were found during the 1930s-1980s. After the late 1980s, we found a statistically significant correlation with observations in most CMIP5 models, and the ensemble CMIP5 converged towards the observations. The ensemble area-averaged MAT had a statistically significant correlation of 0.68 with observations during the

Table 3. Evaluation of Coupled Model Intercomparison Project Phase 5 (CMIP5) models relative to Climatic Research Unit (CRU) temperatures using mean error (ME), mean absolute error (MAE), root-mean-square error (RMSE), standard deviation of the error (SDE), and Pearson correlation (R) of the detrended data

\begin{tabular}{|lrrrrr|}
\hline Model & $\begin{array}{r}\mathrm{ME} \\
\left({ }^{\circ} \mathrm{C}\right)\end{array}$ & $\begin{array}{c}\mathrm{MAE} \\
\left({ }^{\circ} \mathrm{C}\right)\end{array}$ & $\begin{array}{c}\text { RMSE } \\
\left({ }^{\circ} \mathrm{C}\right)\end{array}$ & $\begin{array}{c}\text { SDE } \\
\left({ }^{\circ} \mathrm{C}\right)\end{array}$ & $\mathrm{R}$ \\
\hline CCSM4 & -0.35 & 0.59 & 0.76 & 0.48 & 0.42 \\
CanESM2 & 0.94 & 0.99 & 1.13 & 1.13 & 0.48 \\
FIO-ESM & -0.16 & 0.50 & 0.61 & 0.42 & 0.54 \\
GISS-E2-H & -0.33 & 0.56 & 0.67 & 0.47 & 0.45 \\
GISS-E2-R & -0.39 & 0.54 & 0.70 & 0.51 & 0.41 \\
IPSL-CM5A-LR & -0.88 & 0.90 & 1.08 & 0.87 & 0.38 \\
IPSL-CM5A-MR & 0.01 & 0.50 & 0.65 & 0.44 & 0.20 \\
MIROC-ESM-CHEM & 1.15 & 1.17 & 1.29 & 1.33 & 0.50 \\
MIROC-ESM & 1.39 & 1.40 & 1.51 & 1.56 & 0.48 \\
MIROC5 & 0.41 & 0.64 & 0.78 & 0.67 & 0.31 \\
MPI-ESM-LR & -0.13 & 0.52 & 0.64 & 0.42 & 0.49 \\
MPI-ESM-MR & 0.35 & 0.57 & 0.71 & 0.62 & 0.57 \\
MRI-CGCM3 & -1.31 & 1.32 & 1.44 & 1.27 & 0.38 \\
NorESM1-M & -1.35 & 1.35 & 1.52 & 1.30 & 0.38 \\
bcc-CSm1-1-m & -0.31 & 0.59 & 0.74 & 0.46 & 0.55 \\
bcc-csm1-1 & -0.82 & 0.87 & 1.00 & 0.82 & 0.64 \\
Ensemble & -0.11 & 0.34 & 0.43 & 0.42 & 0.68 \\
\hline
\end{tabular}




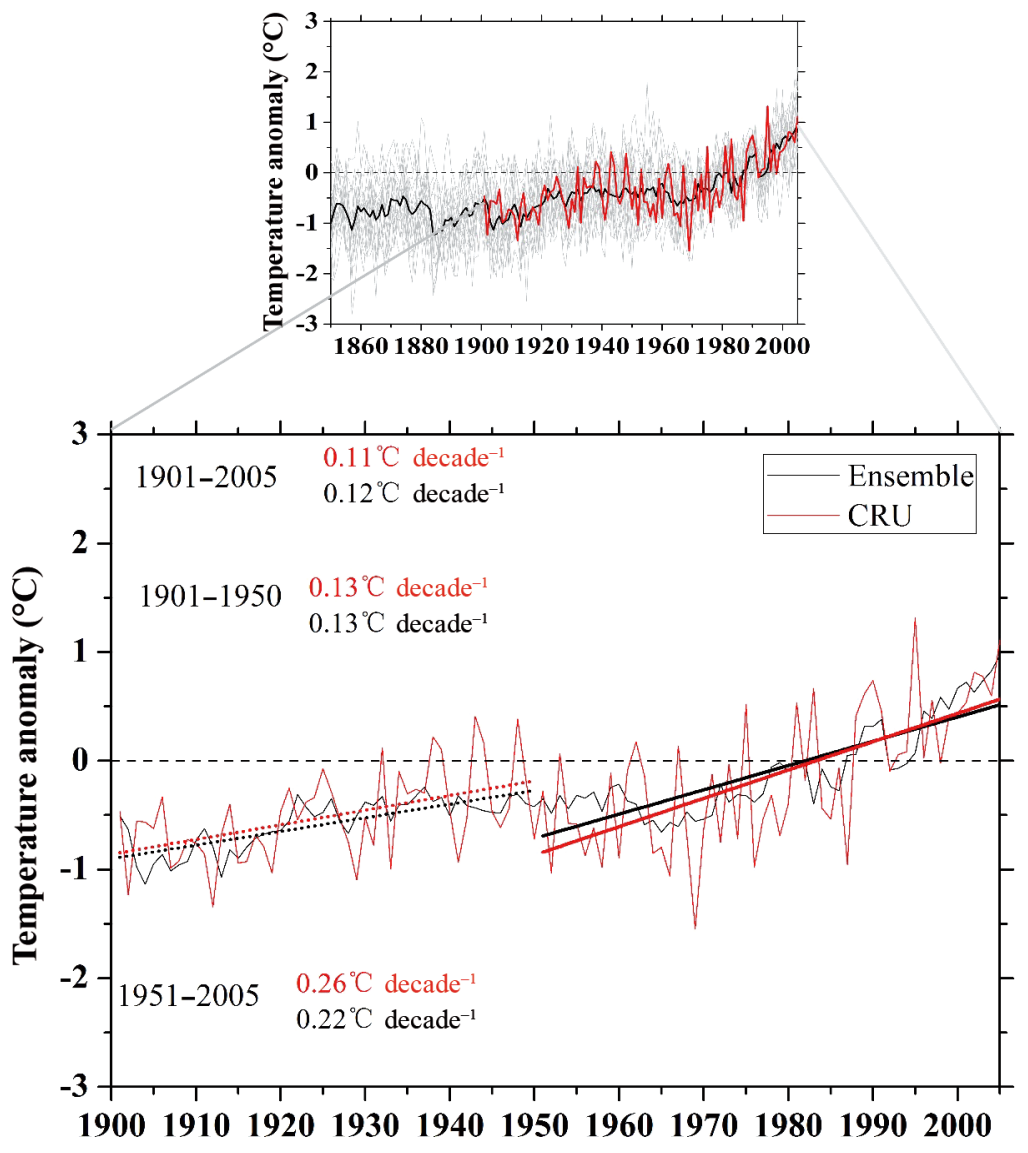

Fig. 2. Time-series of mean annual air temperatures (MAT) derived from Climatic Research Unit (CRU) and Coupled Model Intercomparison Project Phase 5 (CMIP5) data sets over Eurasia from 1901-2005, divided into the early 20th century (1901-1950) and the late 20th century (1951-2005). Top figure: the ensemble CMIP5 model mean air temperature for 18502005 (black), and individual models (grey). Dashed and solid lines: trend of the early 20th and the late 20th century, respectively. Black and red represent the CMIP5 ensemble and CRU, respectively

period 1901-2005. The correlation between the observations and the ensemble area-average was 0.67 in the late 20th century, which was higher than that from the early 20th century data $(0.49)$. Trends of the MAT anomalies of ensemble area-averages and CRU observations tended to be both increasing at a rate of 0.12 and $0.11^{\circ} \mathrm{C}$ decade $^{-1}$ during $1901-2005$. In the early 20th century, both were increasing at the same rate. However, in the late 20th century, MAT derived from the CRU data set was increasing faster, at $0.26^{\circ} \mathrm{C}$ decade $^{-1}$, than the ensemble area-average, at $0.22^{\circ} \mathrm{C}$ decade $^{-1}$.

Multi-model ensemble area-averaging is a common approach to evaluate model output, because it is thought to reduce noise in the projections (Chen \& Frauenfeld 2014). However, individual models were also evaluated (Fig. 3). Agreement between individual CMIP5 models and observations varied among seasons. All 16 models showed good agreement with CRU summer data, based on statistically significant (95\% level) correlations. Overall, 10 models correlated well with CRU in both spring and autumn. However, only 7 models exhibited significant correlations with observations in winter. Among the 16 models, only MIROC-ESMCHEM, MPI-ESM-MR, bcc-csm-1-1-m, and bcc-csm-1-1 showed consistent, good agreement with CRU in all 4 seasons. All models but one have a positive winter temperature bias. This indicates that models project more warming in winter, which is opposite to the other 3 seasons for most models.

\subsection{Changes of surface air temperature in the historical period}

The spatial variation of MAT derived from CRU and CMIP5 ensemble averages during 1971-2000 shows that the warmest regions are in the southeast of China, and the coldest in the north of Siberia (Fig. 4). MATs less than $-4^{\circ} \mathrm{C}$ are mainly located in central and eastern Siberia and the Tibetan Plateau. Spatial MAT patterns from the historical ensemble CMIP5 data set are similar to those from the CRU data, but there are notable differences. We observed a strong cold bias across Eurasia, indicating that multimodel ensemble averages underestimate MAT. The bias is warm in the west and northeast of Siberia, suggesting overestimated temperatures in these regions. The warming trend of CRU and ensemble averages is statistically significant across the vast majority of Eurasia. The largest MAT trends derived from the CRU data set occur between $40-60^{\circ} \mathrm{N}$ at a rate ranging between 0.09 and $0.24^{\circ} \mathrm{C}$ decade $^{-1}$. Spatial patterns of MAT trends derived from ensemble averages exhibit substantial disagreement with the observations. The CMIP5 ensemble average MAT trend captures the fastest warming that appeared in the Arctic area of Eurasia. Accounting for the differences in the MAT trend, this suggests that the multimodel ensemble average overestimates the warming trend in southern and northern Eurasia, and underestimates the warming trend in other regions. 

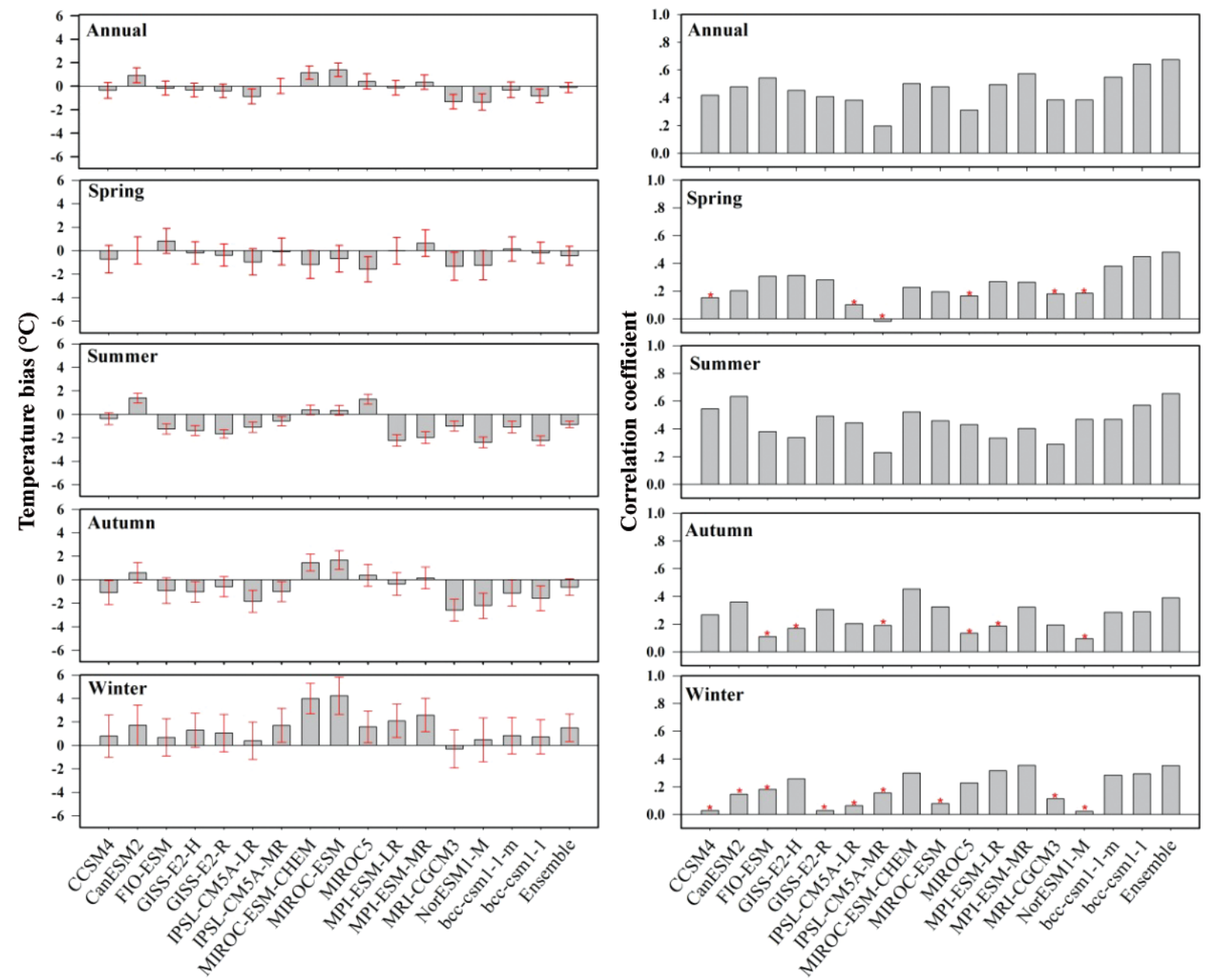

Fig. 3. Comparison of Climatic Research Unit (CRU) and the individual Coupled Model Intercomparison Project Phase 5 (CMIP5) models for annual and seasonal temperatures: (left) temperature bias and (right) correlations between observations and individual models. Error bars indicate standard deviation of temperature biases; red stars indicate non-statistically significant $(95 \%$ level) correlations

In addition to MAT changes, we also analyzed seasonal changes of surface air temperature (Figs. 5 \& 6). The spatial variation of MSAT derived from CRU and CMIP5 ensemble averages are similar in the 4 seasons (Fig. 5). Colder regions are mainly located in the Tibetan Plateau and central and eastern Siberia, while warmer regions occupy southeast China. The differences of MSAT in the 4 seasons are negative in most parts of Eurasia. It is notable that MSAT differences are relatively larger on the Tibetan Plateau, which indicates that the multi-model ensemble averages underestimate surface air temperature. However, differences are positive in the northeast of Eurasia, indicating overestimation of surface air temperature.

Fig. 6 shows the spatial trends of MSAT derived from CRU and CMIP5 ensemble averages. A warming trend is evident across most of the Eurasian land surface. In the CRU data set, a faster warming trend is found in spring and winter than in fall and summer. Especially in winter, the warming rate is greater than $0.2^{\circ} \mathrm{C}$ decade $^{-1}$ in some areas. The warming rate ranges between $0.0-0.1^{\circ} \mathrm{C}$ decade ${ }^{-1}$ across most of the land surface in spring, summer, and autumn. However, a warming rate of $0.1-0.2^{\circ} \mathrm{C}$ decade $^{-1}$ occurs in winter. The differences in the MSAT trend are negative, suggesting that the MSAT derived from CRU is lower than from the CMIP5 ensemble averages across Eurasia.

\subsection{Projected surface air temperature changes}

Over the whole of Eurasia, time-series of ensemble area-averaged MAT from CMIP5 are statistically significant, increasing at $0.074^{\circ} \mathrm{C}$ decade $^{-1}$ during 1850-2005, and $0.078^{\circ} \mathrm{C} \mathrm{decade}^{-1}$ for RCP $2.6,0.72^{\circ} \mathrm{C}$ 

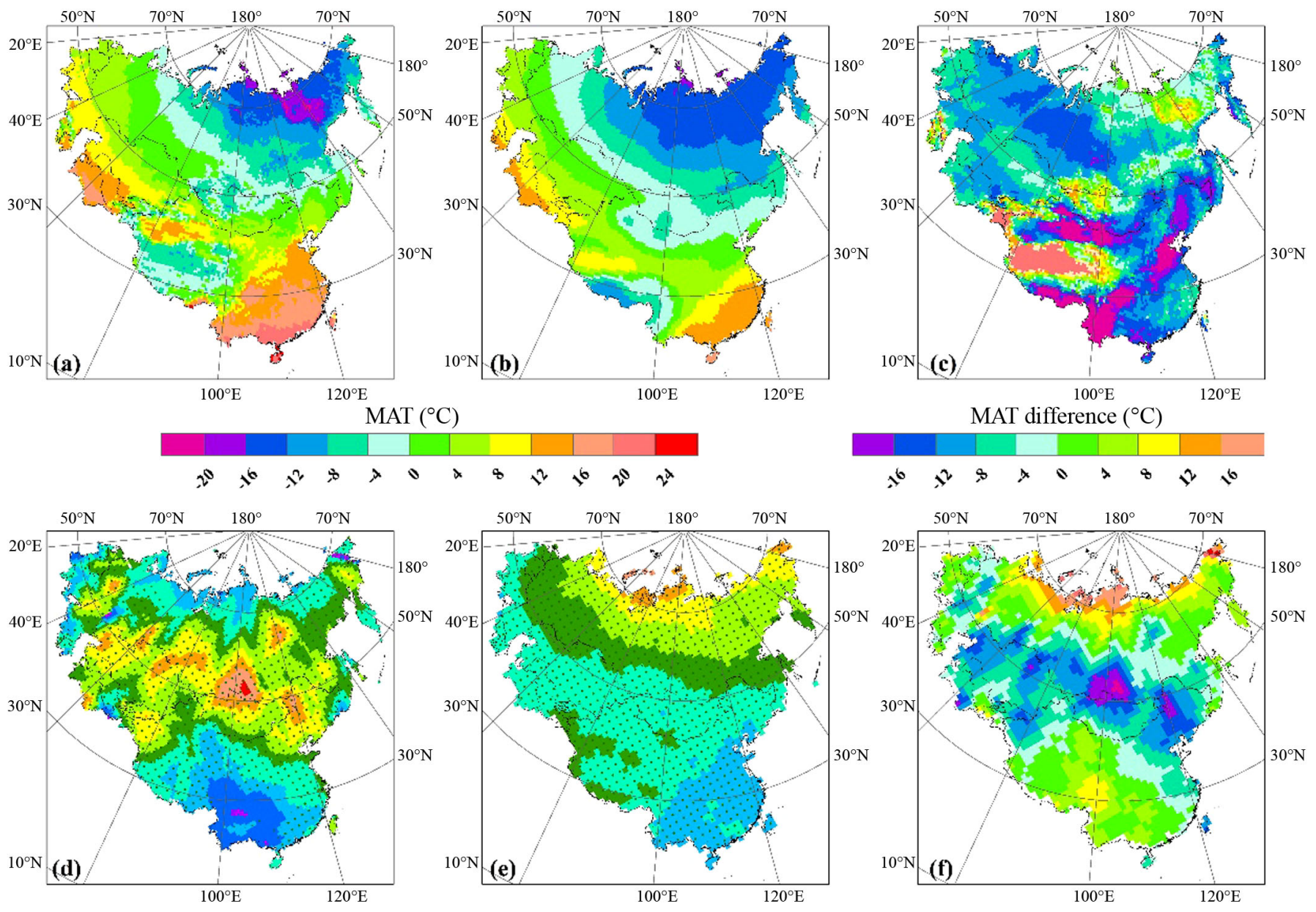

Trend $\left({ }^{\circ} \mathrm{C}\right.$ decade $\left.{ }^{-1}\right)$

Trend difference $\left({ }^{\circ} \mathrm{C}\right.$ decade $\left.{ }^{-1}\right)$

$1: 50000000$
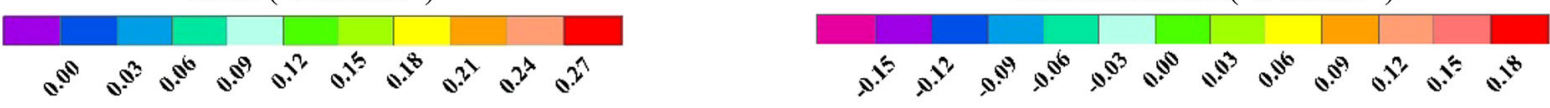

Fig. 4. Spatial temperature patterns derived from Climatic Research Unit (CRU) and Coupled Model Intercomparison Project Phase 5 (CMIP5) ensemble averages over Eurasia for (a) 1971-2000 mean annual air temperature (MAT) values based on CRU, (b) 1971-2000 MAT values based on the ensemble mean of 16 CMIP5 models for the historical experiment, (c) 1971-2000 MAT difference between CMIP5 and CRU, (d) 1901-2005 MAT trends based on CRU, (e) 1901-2005 MAT trends based on the ensemble mean of 16 CMIP5 models, and (f) the 1901-2005 MAT trend difference between CMIP5 and CRU. Dots represent statistically significant (0.05 level) trends

decade $^{-1}$ for RCP 4.5 , and $0.30^{\circ} \mathrm{C}$ decade $^{-1}$ for RCP 8.5 during 2006-2100 (Fig. 7). The increase of ensemble area-averaged mean surface temperatures for 2081-2100 relative to $1986-2005$ is projected to likely be $1.68^{\circ} \mathrm{C}(\mathrm{RCP} 2.6), 3.18^{\circ} \mathrm{C}(\mathrm{RCP} 4.5)$, or $6.41^{\circ} \mathrm{C}$ (RCP 8.5).

To investigate projected MAT changes, we examined the spatial pattern of MAT in the 3 RCPs, and compared differences to the historical experiment (Fig. 8). The spatial pattern of MAT is consistent among the 3 RCPs: temperatures increase with increasing latitude and decreasing elevation. The coldest regions are on the Tibetan Plateau, and central and eastern Siberia. The differences be- tween RCPs and the historical experiment were positive over Eurasia, which indicates a warming climate in the future. Due to its low radiative forcing, the RCP 2.6 experiment projects the smallest increase, mainly less than $2^{\circ} \mathrm{C}$. The RCP 4.5 and RCP 8.5 experiments project faster temperature increases, ranging $2-3^{\circ} \mathrm{C}$, but also exceeding $3^{\circ} \mathrm{C}$. The spatial patterns of MAT trends derived from the CMIP5 ensemble in the $3 \mathrm{RCP}$ experiments during 2006-2100 are similar. The trends of surface air temperature increase from RCP 2.6 to RCP 8.5. The rates of increase in RCP 2.6, 4.5, and 8.5 were mostly $<0.1$, between $0.2-0.3$, and $>0.4^{\circ} \mathrm{C}$ decade $^{-1}$, respectively. 

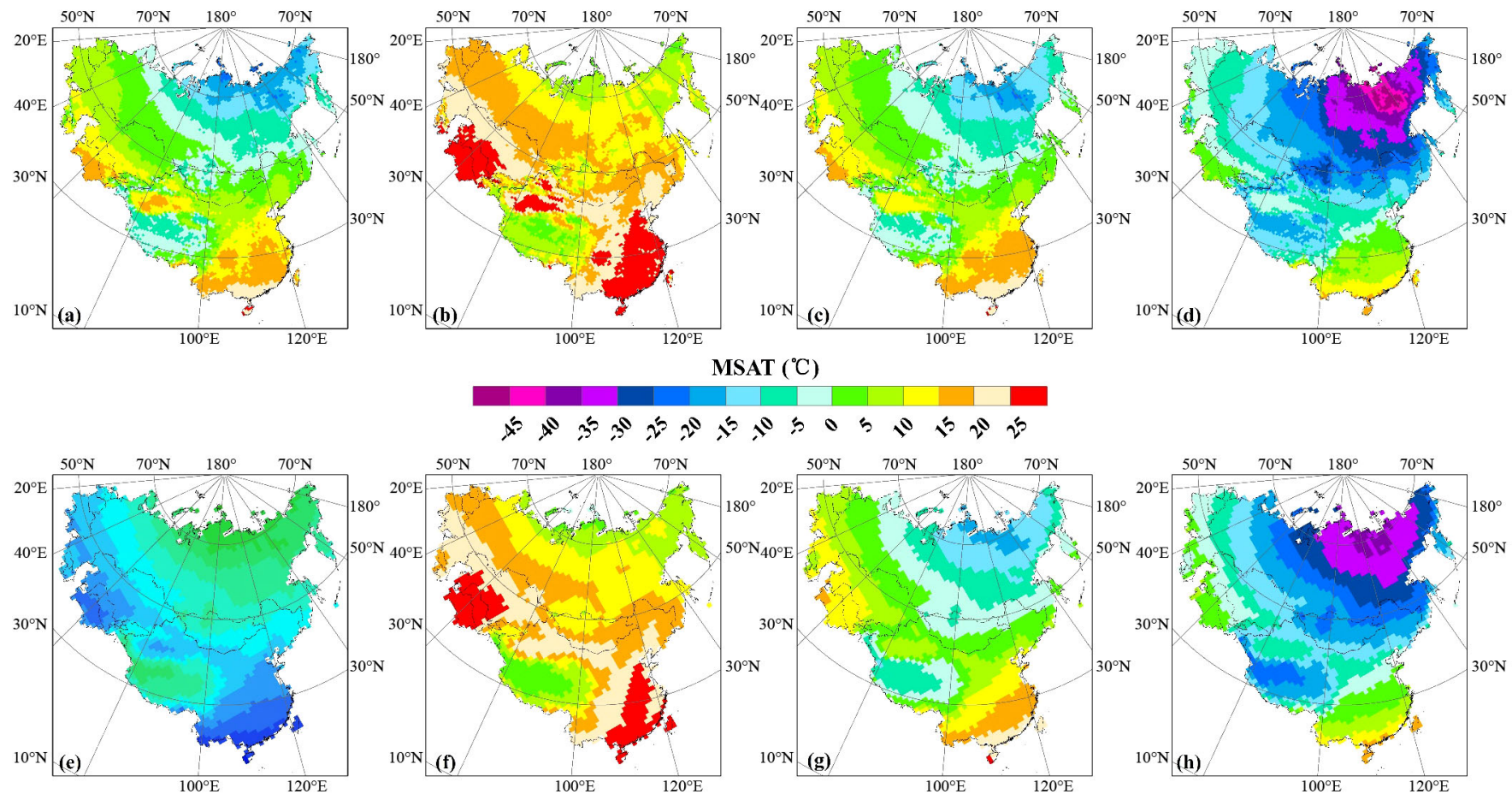

MSAT $\left({ }^{\circ} \mathrm{C}\right)$
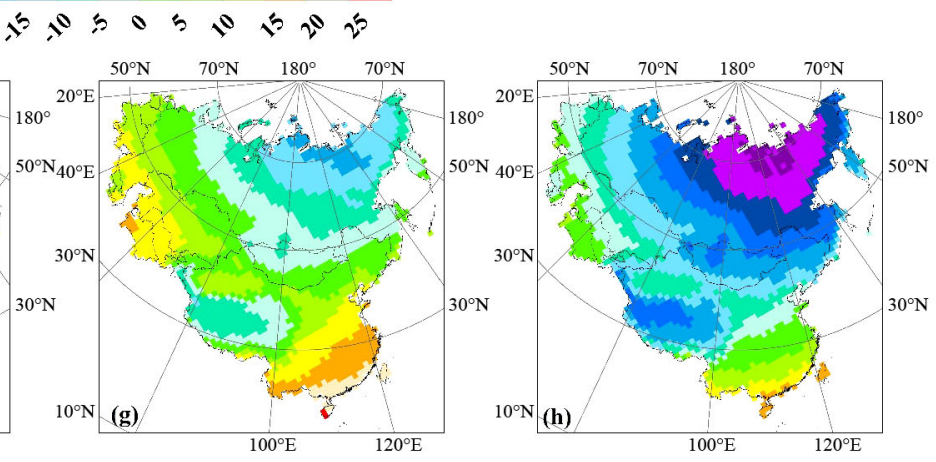

MSAT $\left({ }^{\circ} \mathrm{C}\right)$

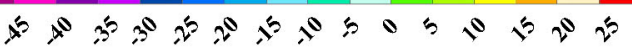
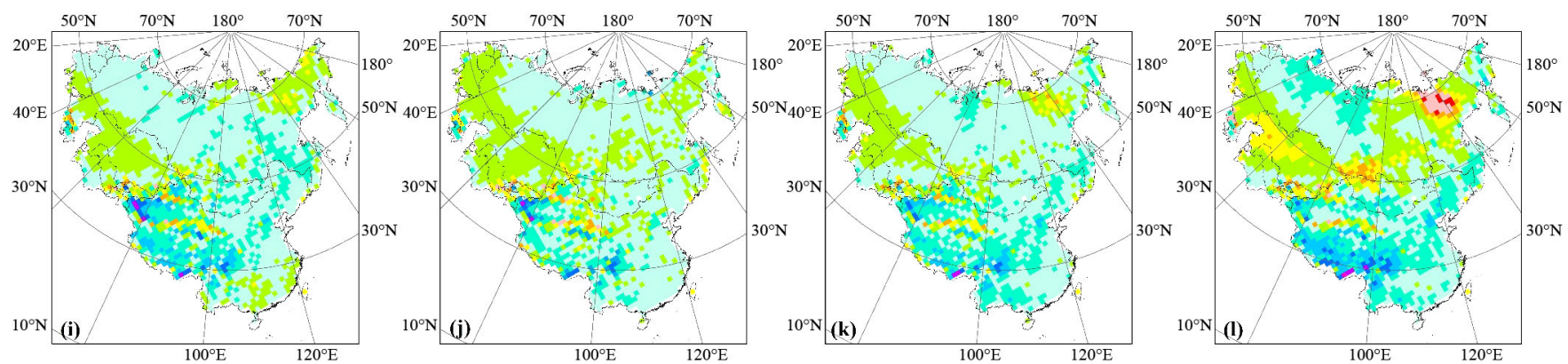

$1: 50000000$

MSAT Difference $\left({ }^{\circ} \mathrm{C}\right)$

$$
5,96303692
$$

Fig. 5. Spatial patterns of mean seasonal air temperature (MSAT) based on 1971-2000 Climatic Research Unit (CRU) data for (a) spring, (b) summer, (c) autumn, (d) winter, and based on the ensemble mean of 16 Coupled Model Intercomparison Project Phase 5 (CMIP5) models for the historical experiment (1971-2000) in (e) spring, (f) summer, (g) autumn, and (h) winter; (i-l) represent the MSAT differences (CMIP5-CRU) for spring, summer, autumn, and winter, respectively

\subsection{Surface air temperature changes in frozen ground regions}

To investigate and quantify surface air temperature change in different frozen ground regions, we divided Eurasia into CPF, DCPF, SIRPF, and NonPF regions. We calculated the time-series of ensemble area-averaged MAT in these regions during 18502100 in the 4 experiments (Fig. 9, Table 4). There is a statistically significant increasing trend in the MAT anomalies for the 4 experiments. In the historical experiment, we found a gradual increase in MAT from $1850-2005$ at a rate of $0.10^{\circ} \mathrm{C}$ decade $^{-1}$ in $\mathrm{CPF}_{\text {, }}$ $0.072^{\circ} \mathrm{C}$ decade $^{-1}$ in DCPF, $0.064^{\circ} \mathrm{C}$ decade $^{-1}$ in $\mathrm{SIRPF}$, and $0.062^{\circ} \mathrm{C}$ decade ${ }^{-1}$ in NonPF regions. The RCP 2.6 scenario projected an increase in MAT at a rate of $0.10,0.075,0.068$, and $0.07^{\circ} \mathrm{C}$ decade $^{-1}$ in $C P F$, $\mathrm{DCPF}, \mathrm{SIRPF}$, and NonPF regions, respectively. The 

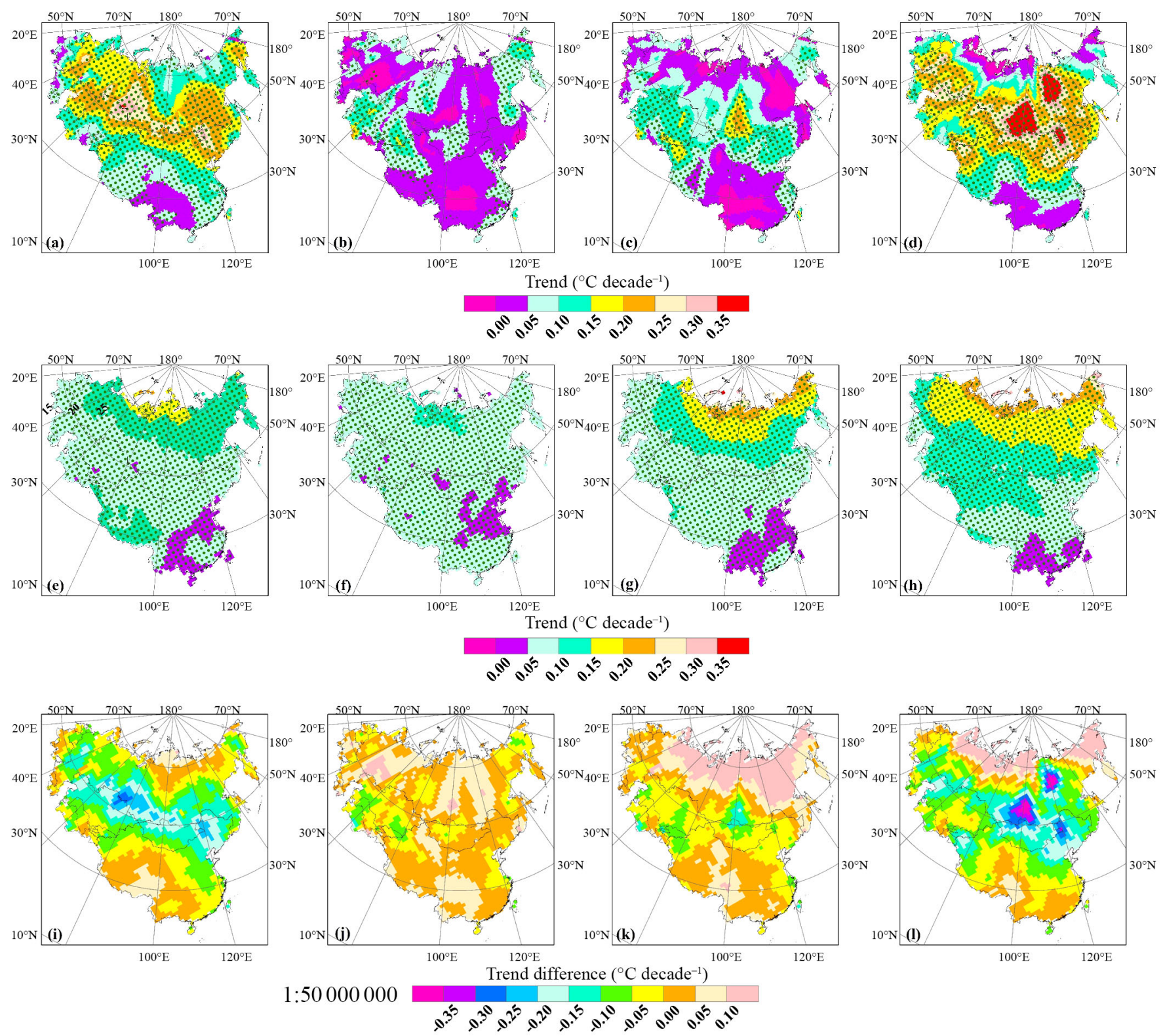

Fig. 6. Spatial mean seasonal air temperature (MSAT) patterns over Eurasia for 1901-2005 Climatic Research Unit (CRU) data for (a) spring, (b) summer, (c) autumn, (d) winter, and for the ensemble mean of 16 Coupled Model Intercomparison Project Phase 5 (CMIP5) models for the 1901-2005 historical experiment for (e) spring, (f) summer, (g) autumn, (h) winter; (i-l) represent the mean seasonal air temperature (MSAT) trend differences (CMIP5-CRU) for spring, summer, autumn, and winter, respectively; green dots: statistically significant ( 0.05 level) trends

RCP 4.5 scenario presented an increase in MAT at a rate of $0.36,0.29,0.28$, and $0.27^{\circ} \mathrm{C}$ decade $^{-1}$ in $\mathrm{CPF}$, DCPF, SIRPF, and NonPF regions, respectively. The RCP 8.5 scenario exhibited the greatest increases in MAT at a rate of $0.85,0.71,0.69$, and $0.66^{\circ} \mathrm{C}$ eecade $^{-1}$ in $\mathrm{CPF}$, DCPF, SIRPF, and NonPF regions, respectively. For all 4 RCP experiments, we found that fastest to slowest rates of increase, in order, are $\mathrm{CPF}$, DCPF, SIRPF, and the NonPF regions.

\section{DISCUSSION}

One of the goals of our study was to evaluate CMIP5 model performance in simulating surface air temperature relative to the CRU observational data set. In the early 20th century, the correlation between multimodel ensemble averages and CRU was only 0.49, which is lower than the 0.67 we found for the late 20th century. This is likely due to the number of observing 


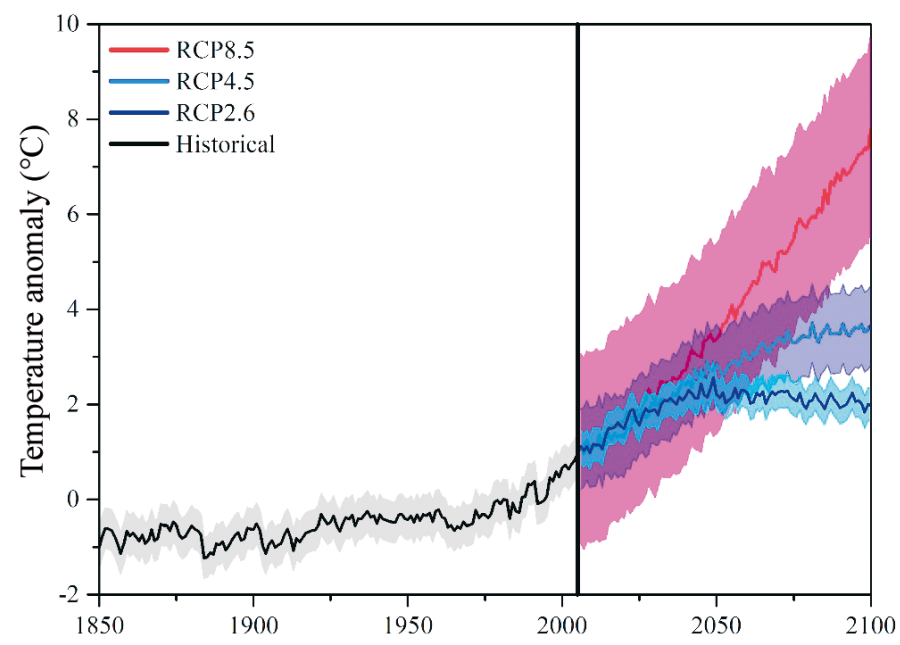

Fig. 7. Time-series of annual mean surface air temperature anomalies with respect to 1971-2000 for the 1850-2005 historical experiment and 2006-2100 RCP 2.6, RCP 4.5, and RCP 8.5 over Eurasia. Shading corresponds to one standard deviation

stations increasing over time, improving data quality in the late 20th century, and also due to improvements in CMIP5 model simulations (Zhao et al. 2014). Although GCMs are a useful method to simulate past and projected climate change at a large or global

Table 4. Trends of mean annual surface air temperature for continuous permafrost (CPF), discontinuous permafrost (DCPF), sporadic, isolated, and relict permafrost (SIRPF), and non-permafrost (NonPF) regions

\begin{tabular}{|lcccc|}
\hline & $\begin{array}{c}\text { Historical } \\
\left({ }^{\circ} \mathrm{C} \text { decade }{ }^{-1}\right)\end{array}$ & $\begin{array}{c}\mathrm{RCP} 2.6 \\
\left({ }^{\circ} \mathrm{C} \text { decade }{ }^{-1}\right)\end{array}$ & $\begin{array}{c}\mathrm{RCP} 4.5 \\
\left({ }^{\circ} \mathrm{C} \mathrm{decade}^{-1}\right)\end{array}$ & $\begin{array}{c}\mathrm{RCP} 8.5 \\
\left({ }^{\circ} \mathrm{C} \text { decade }^{-1}\right)\end{array}$ \\
\hline $\mathrm{CPF}$ & 0.10 & 0.10 & 0.36 & 0.85 \\
$\mathrm{DCPF}$ & 0.072 & 0.075 & 0.27 & 0.71 \\
SIRPF & 0.064 & 0.068 & 0.28 & 0.69 \\
NonPF & 0.062 & 0.07 & 0.27 & 0.66 \\
\hline
\end{tabular}

scale, with many improvements in the past, there are still uncertainties. To reduce the uncertainties and improve climate change simulations, dynamical (Giorgi et al. 2009) and statistical downscaling techniques can be useful to improve the resolution. Regional climate models (RCMs) are widely used in downscaling GCM projections to the regional scale. Typically, compared to the driving GCMs, the RCMs not only show more detailed geographical features, but also provide an improved representation of the large-scale patterns (Gao \& Giorgi 2017). Especially regions such as Eurasia, underlain by frozen ground with extensive snow cover, need improved and detailed physical processes to simulate surface air temperature. More generally, increased development and testing of coupled atmosphere-ocean-cryosphere RCMs are necessary to better describe the complex and highly non-linear interactions between climate and the cryosphere, to enhance the reliability of climate projections in cold regions (Giorgi \& Gao 2018).

Interestingly, the warming rate is different for different land-surface types (Table 5). Previous studies have indicated that the global land surface air temperature warmed at $0.067^{\circ} \mathrm{C}$ decade ${ }^{-1}$ during $1880-$ 1999 (data from 19 CMIP3 models; Zhou \& Yu 2006), $0.07^{\circ} \mathrm{C}$ decade $^{-1}$ from 1930-2004 (data from 19 CMIP5 models; Kumar et al. 2013), or $0.08^{\circ} \mathrm{C}$ decade ${ }^{-1}$ for 1930-2004 (CRU data set; Kumar et al. 2013). Chen \& Frauenfeld (2014) reported that the regionally averaged MAT from 20 CMIP5 models increased at a rate of $0.045^{\circ} \mathrm{C}$ decade ${ }^{-1}$ during 1901-2005 in China, and $0.054^{\circ} \mathrm{C}$ de$\mathrm{cade}^{-1}$ on the Tibetan Plateau. The increase was $0.068^{\circ} \mathrm{C}_{\text {decade }}{ }^{-1}$ for $1880-1999$ in the Northern Hemisphere (Zhou \& Yu 2006). Greater warming trends were found for the Arctic.

Compared with these previous studies, our results of $0.14^{\circ} \mathrm{C}$ decade ${ }^{-1}$ warming show a slightly higher warming rate for Eurasia than

Table 5. Trends of mean annual surface air temperature in different regions based on previous studies and data sets

\begin{tabular}{|c|c|c|c|c|}
\hline Regions & Trend $\left({ }^{\circ} \mathrm{C}\right.$ decade $\left.{ }^{-1}\right)$ & Period & CMIP models & Reference \\
\hline China & 0.045 & $1901-2005$ & 20 CMIP5 & Chen \& Frauenfeld (2014) \\
\hline Tibetan Plateau & 0.054 & 1901-2005 & 20 CMIP5 & Chen \& Frauenfeld (2014) \\
\hline Global & 0.067 & 1880-1999 & 19 CMIP3 & Zhou \& Yu (2006) \\
\hline Northern Hemisphere & 0.068 & 1880-1999 & 19 CMIP3 & Zhou \& Yu (2006) \\
\hline Arctic & 0.136 & $1875-2008$ & Station and reanalysis dataset2 & Bekryaev et al. (2010) \\
\hline Global & 0.070 & 1930-2004 & 19 CMIP5 & Kumar et al. (2013) \\
\hline Global & 0.080 & $1930-2004$ & CRU & Kumar et al. (2013) \\
\hline Eurasia & 0.12 & $1901-2005$ & 16 CMIP5 & This study \\
\hline Eurasia & 0.11 & $1901-2005$ & CRU & This study \\
\hline Eurasia & 0.074 & $1850-2005$ & 16 CMIP5 & This study \\
\hline
\end{tabular}



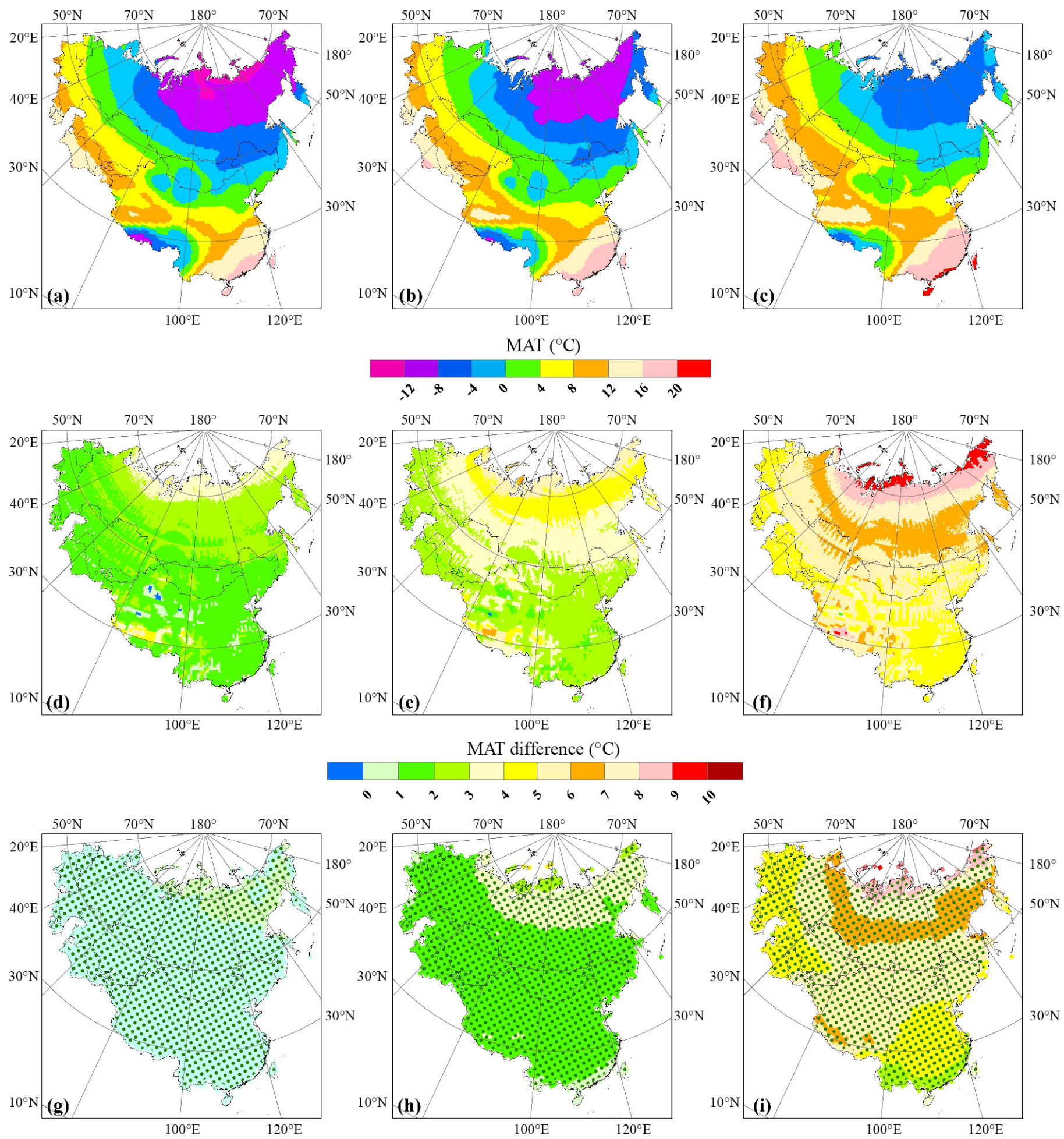

$1: 50000000$

Trend $\left({ }^{\circ} \mathrm{C}\right.$ decade $\left.^{-1}\right)$

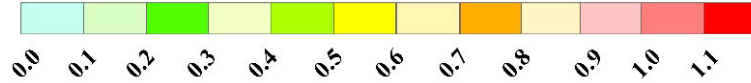

Fig. 8. Projected patterns of mean annual air temperature (MAT) over Eurasia, showing 2071-2100 MAT values for (a) RCP 2.6, (b) RCP 4.5, and (c) RCP 8.5. Projected MAT differences for 2071-2100 minus 1971-2000 in (d) RCP 2.6, (e) RCP 4.5, and (f) RCP 8.5 and 2006-2100 MAT trends for (g) RCP 2.6, (h) RCP 4.5, (i) RCP 8.5. Green dots: statistically significant (0.05 level) trends 

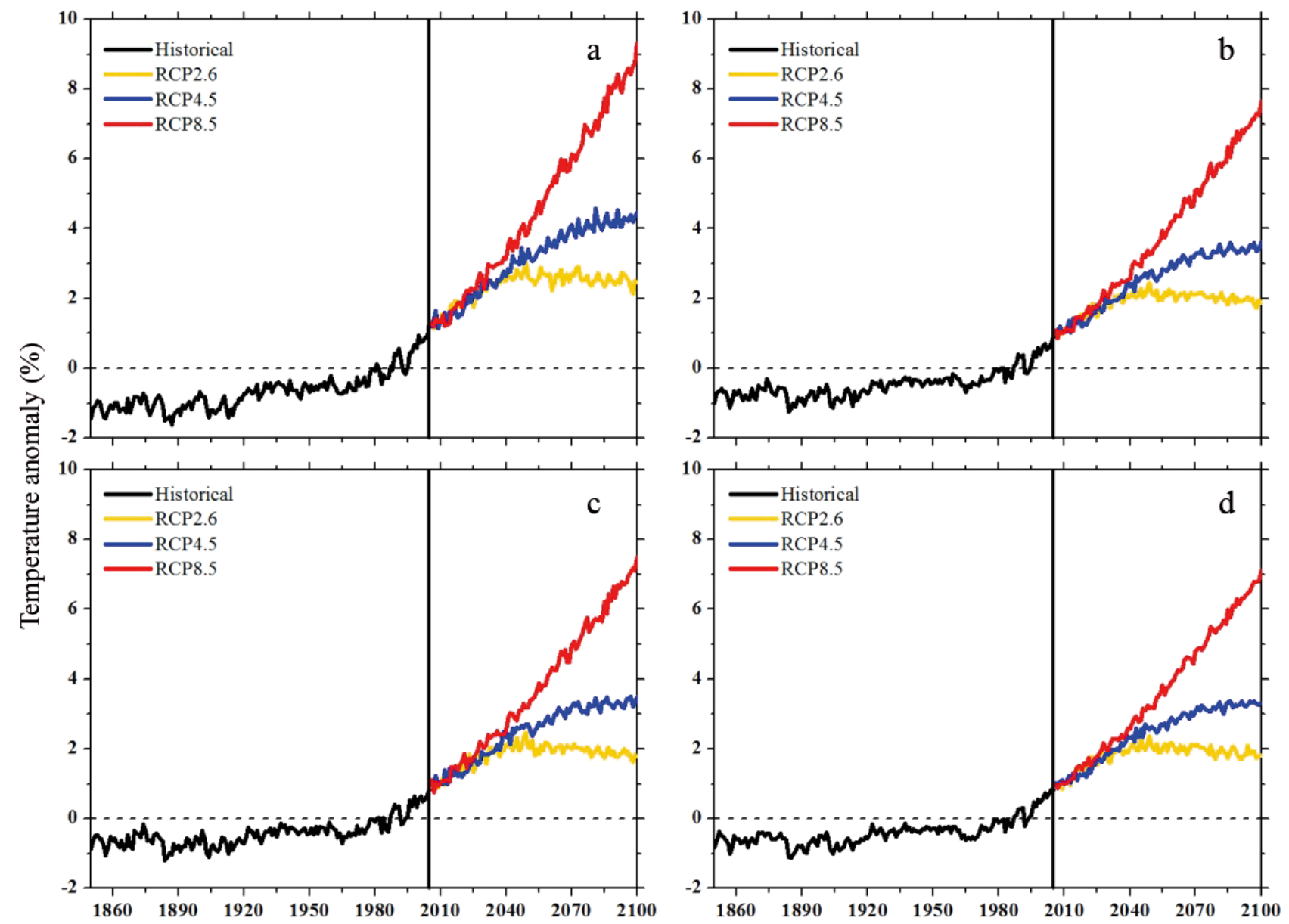

Fig. 9. Time-series of 1850-2100 surface air temperatures over Eurasia from different Coupled Model Intercomparison Project Phase 5 (CMIP5) experiments for (a) continuous permafrost, (b) discontinuous permafrost, (c) sporadic, isolated, and relict permafrost, and (d) non-permafrost regions

for the Northern Hemisphere and the global region, but lower than in the Arctic. The greater warming in Eurasia is likely because, in general, large areas of Eurasia are in high latitudes, and some at very high elevations. Previous studies have indicated that high latitude warming is greater due to the ice-albedo feedback mechanism (e.g. Serreze \& Francis 2006, Bekryaev et al. 2010). Furthermore, research has suggested that high elevation regions experienced faster warming rates, referred to as elevation-dependent warming (EDW; Pepin et al. 2015). Pepin et al. (2015) also indicated important mechanisms such as snow albedo feedbacks, surface-based feedbacks, water vapor changes, and latent heat release, all contributing to EDW.

Much of Eurasia is covered by frozen ground (Fig. 1, Table1). Zhong et al. (2014) suggested that Eurasia is the primary snow region in the Northern Hemisphere, and accounts for $60-65 \%$ of all winter snow. The snow-covered period lasts for $8 \mathrm{mo}$ in
Arctic Russia (Parkinson 2006, Bulygina et al. 2009). The cryosphere, a component of the global climate system, plays an important role in the energy exchange and the hydrologic cycle at the land surface. Further, it is often considered a global climate change indicator due to its key components of snow, glaciers, sea/lake/river ice, and frozen ground. The most sensitive components are permafrost and snow, in comparison with other land surface elements. The cryosphere is not only a climate indicator, but also an amplifier of climatic warming. The degree and rate of climate change in cryospheric regions are generally greater and faster than in other regions. Furthermore, changes in the cryosphere result in positive feedbacks with climate, enhancing warming (Cheng 1996, Allison et al. 2001, Li et al. 2008, IPCC 2013). In our study, we found that the warming rate of surface air temperature in permafrost regions is faster than in non-permafrost regions. 


\section{CONCLUSIONS}

This study evaluated the performance of 16 CMIP5 models in simulating surface air temperature variability over Eurasia during the 20th century with respect to CRU observations. For seasonal and annual mean temperatures, CMIP5 shows substantial cold biases over the Tibetan Plateau, especially in the cold season. Some warm bias occurs in the northwest of Eurasia. In the late 20th century, the CMIP5 ensemble averages show slightly better agreement than in the early 20th century. Both CMIP5 ensemble averages and CRU observations demonstrate climate warming over the 20th century, with accelerated warming during the late 20th century.

The future temperature projections for Eurasia indicate that the RCP 8.5, RCP 4.5 and RCP 2.6 scenarios exhibit statistically significant increases in annual temperature during the 21st century at a rate of $0.72,0.230$ and $0.078^{\circ} \mathrm{C}$ decade $^{-1}$ during $2006-$ 2100 , respectively. The increase of regional-scale mean surface temperatures for 2081-2100 relative to $1986-2005$ is projected to be $1.68^{\circ} \mathrm{C}(\mathrm{RCP} 2.6), 3.18^{\circ} \mathrm{C}$ (RCP 4.5), or $6.41^{\circ} \mathrm{C}$ (RCP 8.5). Surface air temperature changes in frozen ground regions demonstrated that the fastest increases occur in the CPF regions, next in DCPF regions, followed by SIRPF regions, with lowest warming in NonPF regions for each RCP scenario.

Acknowledgements. This study was supported the National Natural Science Foundation of China (grant No. 41801028, 91325202), the State Key Laboratory of Frozen Soil Engineering (SKLFSE201707), the Strategic Priority Research Program of Chinese Academy of Sciences (Grant No. XDA20100103), the Open Foundation of Research institute of Qilian Mountains, Lanzhou University (grant No. 504000[87080311]), and the Fundamental Research Funds for the Central Universities (grant No. lzujbky-2018-47). We acknowledge the international modeling groups for providing their data, the Program for Climate Model Diagnosis and Inter-comparison (PCMDI) for collecting and achieving the model data.

\section{LITERATURE CITED}

Allison I, Barry RG, Goodison BE (2001) Climate and cryosphere $(\mathrm{CliC})$ project science and co-ordination plan: version 1. Joint Planning Staff for WCRP, World Meteorological Organization, Geneva

Bekryaev RV, Polyakov IV, Alexeev VA (2010) Role of polar amplification in long-term surface air temperature variations and modern Arctic warming. J Clim 23:3888-3906

Brown J, Romanovsky VE (2008) Report from the International Permafrost Association: state of permafrost in the first decade of the 21st century. Permafr Periglac Process 19:255-260
Brown IE, Ferrians OJ, Heginbottom JA, Melnikov ES, Regional JA (1998) Circum-Arctic map of permafrost and ground-ice conditions. National Snow and Ice Data Center/World Data Center for Glaciology, Boulder, CO

*Bulygina ON, Razuvaev VN, Korshunova NN (2009) Changes in snow cover over northern Eurasia in the last few decades. Environ Res Lett 4:045026

Chapin FS, Sturm M, Serreze MC, McFadden JP and others (2005) Role of land-surface changes in Arctic summer warming. Science 310:657-660

Chen L, Frauenfeld OW (2014) Surface air temperature changes over the twentieth and twenty-first centuries in China simulated by 20 CMIP5 models. J Clim 27: 3920-3937

Cheng GD (1996) The role of cryosphere in climate change. In: Proc Fifth Natl Conf Glaciology and Geocryology. Gansu Culture Press, Lanzhou, p 807-817

Gao XJ, Giorgi F (2017) Use of the RegCM system over East Asia: review and perspectives. Engineering (Beijing) 3: 766-772

Giorgi F, Gao XJ (2018) Regional earth system modeling: review and future directions. Atmos Ocean Sci Lett 11: 189-197

Giorgi F, Jones C, Asrar GR (2009) Addressing climate information needs at the regional level: the CORDEX frame. WMO Bull 3:175-183

*Guo Y, Dong WJ, Ren FM, Zhao ZC, Huang JB (2013) Surface air temperature simulations over China with CMIP5 and CMIP3. Adv Clim Chang Res 4:145-152

* Harris I, Jones PD, Osborn TJ, Lister DH (2014) Updated high resolution grids of monthly climatic observationsthe CRU TS3.10 dataset. Int J Climatol 34:623-642

IPCC (2013) Climate change 2013: the physical science basis. In: Stocker TF, Qin D, Plattner GK, Tignor M and others (eds) Contribution of Working Group I to the Fifth Assessment Report of the Intergovernmental Panel on Climate Change. Cambridge University Press, Cambridge, p 161-162

Jeong JH, Kug JS, Kim BM, Min SK, Linderholm HW, Ho $\mathrm{CH}$, Jun SY (2012) Greening in the circumpolar high-latitude may amplify warming in the growing season. Clim Dyn 38:1421-1431

Jiang YM, Wu HM (2013) Simulation capabilities of 20 CMIP5 models for annual mean air temperatures in central Asia. Progressus Inquisitiones De Mutatione Climatis 9:110-116

Joetzjer E, Douville H, Delire C, Ciais P (2013) Present-day and future Amazonian precipitation in global climate models: CMIP5 versus CMIP3. Clim Dyn 41:2921-2936

*Kumar S, Merwade V, Kinter JLI, Niyogi D (2013) Evaluation of temperature and precipitation trends and longterm persistence in CMIP5 twentieth-century climate simulations. J Clim 26:4168-4185

Li X, Cheng G, Jin H, Kang E, Che T, Jin R, Shen Y (2008) Cryospheric change in China. Global Planet Change 62: 210-218

KLindvall J, Svensson G (2015) The diurnal temperature range in the CMIP5 models. Clim Dyn 44:405-421

Oleson KW, Lawrence DM, Bonan GB, Drewniak B and others (2013) Technical description of version 4.5 of the Community Land Model (CLM). NCAR Technical Note NCAR/TN-503+STR. National Center for Atmospheric Research, Boulder CO

* Parkinson CL (2006) Earth's cryosphere: current state and recent changes. Annu Rev Environ Resour 31:33-60 
Pepin N, Bradley RS, Diaz HF, Baraer M and others (2015) Elevation-dependent warming in mountain regions of the world. Nat Clim Chang 5:424-430

Riahi K, Rao S, Krey V, Cho C, Chirkov V, Fischer G, Rafaj P (2011) RCP 8.5 - a scenario of comparatively high greenhouse gas emissions. Clim Change 109:33-57

Romanovsky VE, Drozdov DS, Oberman NG, Malkova GV, Kholodov AL, Marchenko SS, Gilichinsky DA (2010) Thermal state of permafrost in Russia. Permafr Periglac Process 21:136-155

Rothrock DA, Yu Y, Maykut GA (1999) Thinning of the Arctic sea ice cover. Geophys Res Lett 26:3469-3472

* Schuur EA, McGuire AD, Schädel C, Grosse G, Harden JW, Hayes DJ, Natali SM (2015) Climate change and the permafrost carbon feedback. Nature 520:171-179

Screen JA, Simmonds I (2010) The central role of diminishing sea ice in recent Arctic temperature amplification. Nature 464:1334-1337

Serreze MC, Francis JA (2006) The Arctic amplification debate. Clim Change 76:241-264

Serreze MC, Walsh JE, Chapin FS III, Osterkamp T and others (2000) Observational evidence of recent change in the northern high-latitude environment. Clim Change 46:159-207

Shackley S, Young P, Parkinson S, Wynne B (1998) Uncertainty, complexity and concepts of good science in climate change modelling: Are GCMs the best tools? Clim Change 38:159-205

Sillmann J, Kharin VV, Zhang X, Zwiers FW, Bronaugh D (2013) Climate extremes indices in the CMIP5 multimodel ensemble: Part 1. Model evaluation in the present climate. J Geophys Res D Atmospheres 118:1716-1733

Taylor KE, Stouffer RJ, Meehl GA (2012) An overview of CMIP5 and the experiment design. Bull Am Meteorol Soc 93:485-498

Thomson AM, Calvin KV, Smith SJ, Kyle GP, Volke A, Patel P, Edmonds JA (2011) RCP4.5: a pathway for stabiliza-

Editorial responsibility: Filippo Giorgi,

Trieste, Italy tion of radiative forcing by 2100. Clim Change 109:77-94

*Van Vuuren DP, Meinshausen M, Plattner GK, Joos F, Strassmann KM and others (2008) Temperature increase of 21st century mitigation scenarios. Proc Natl Acad Sci USA 105:15258-15262

Wuebbles D, Meehl G, Hayhoe K, Karl TR, Kunkel K, Santer B, Goodman A (2014) CMIP5 climate model analyses: climate extremes in the United States. Bull Am Meteorol Soc 95:571-583

Xia K, Wang B, Li L, Shen S, Huang W, Xu S, Liu L (2014) Evaluation of snow depth and snow cover fraction simulated by two versions of the flexible global oceanatmosphere-land system model. Adv Atmos Sci 31: 407-420

Xu Y, Xu CH (2012) Simulations of climate changes over China by CMIP5 multi-models. Atmos Ocean Sci Lett 5: 489-494

Xu Y, Gao XJ, Shi Y, Zhou BT (2015) Detection and attribution analysis of annual mean temperature changes in China. Clim Res 63:61-71

Zhang TJ, Barry RG, Knowles K, Ling F, Armstrong RL (2003) Distribution of seasonally and perennially frozen ground in the Northern Hemisphere. In: Phillips M, Springman S, Arenson L (eds) Proc 8th Int Conf Permafrost. AA Balkema Publishers, Leiden, p 1289-1294

Zhao T, Chen L, Ma Z (2014) Simulation of historical and projected climate change in arid and semiarid areas by CMIP5 models. Chin Sci Bull 59:1148-1163

Zhong X, Zhang T, Wang K (2014) Snow density climatology across the former USSR. Cryosphere 8:785-799

Zhong X, Zhang T, Kang S, Wang K, Zheng L, Hu Y, Wang H (2018) Spatiotemporal variability of snow depth across the Eurasian continent from 1966 to 2012. Cryosphere 12:227-245

* Zhou T, Yu R (2006) Twentieth-century surface air temperature over China and the globe simulated by coupled climate models. J Clim 19:5843-5858

Submitted: April 10, 2018; Accepted: November 29, 2018 Proofs received from author(s): January 21, 2019 